\title{
CAMINHABILIDADE, PAISAGEM E AMBIÊNCIA NO CENTRO HISTÓRICO DE GOIÁS (GO)
}

\author{
WALKABILITY, LANDSCAPE AND URBAN DESIGN \\ IN THE HISTORIC CENTER OF GOIÁS (GO)
}

\author{
Carina Folena Cardoso* \\ Thalita Pereira Fonseca** \\ Pedro Henrique Gonçalves***
}

\section{RESUMO}

Este trabalho relaciona os níveis de caminhabilidade do centro histórico da cidade de Goiás (GO) com a contemplação de sua paisagem cultural em percursos ordinários. A investigação se dá através de abordagens quantitativas e qualitativas a partir de três perspectivas: distâncias percorridas; qualidade dos ambientes contemplados nos percursos; paisagem. Como desdobramento dos procedimentos metodológicos e dos resultados encontrados, discute-se sobre a contribuição do estudo da qualidade paisagística e ambiental à análise da caminhabilidade, procurando superar uma avaliação segmentária desta. Os resultados apresentam índices abaixo da média para todos os percursos, o que dificilmente enquadraria a cidade de Goiás no rol das chamadas "cidades ativas" por suas deficiências no âmbito da caminhabilidade.

Palavras-chave: Caminhabilidade. Ambiência urbana. Paisagem urbana. Visão serial. Cidades pequenas.

\section{ABSTRACT}

This article lists the walkability levels in the historic center of the city of Goiás, contemplating its cultural landscape in ordinary paths. The investigation was carried out from quantitative and qualitative approaches through three different perspectives: distances travelled; quality of the environments included in the routes, and landscape. As a development of the methodological proceedings and the results found, it sets a discussion about the contribution of studying landscape and environmental qualities as an improvement of the walkability analysis, in an effort to overcome a segmented evaluation of the latter. The results show rates below average for all paths, which would hardly allow Goiás to take part in the so-called 'active cities' list, due to its deficiencies in the scope of walkability.

Keywords: Walkability. Urban Environment. Urban Landscape. Serial Vision. Small Towns.

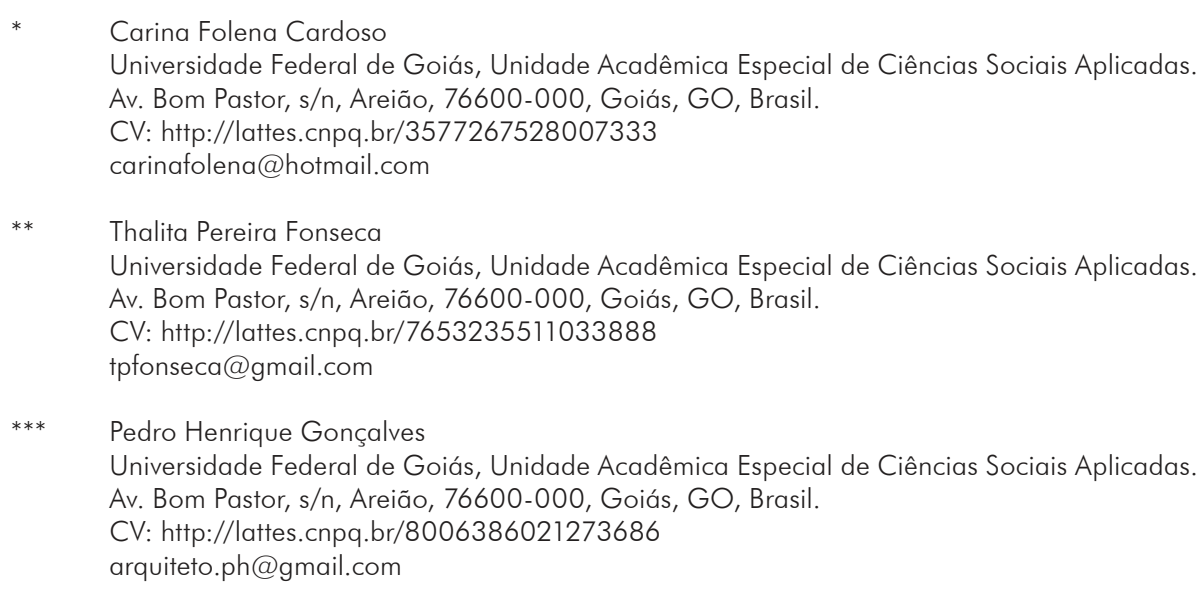




\section{INTRODUÇÃO}

Beco da minha terra...

Amo tua paisagem triste, ausente e suja. Teu ar sombrio. Tua velha umidade andrajosa.

Teu lodo negro, esverdeado, escorregadio.

E a réstia de sol que ao meio-dia desce, fugidia,

E semeia polmes dourados no teu lixo pobre, Calçando de ouro a sandália velha, Jogada no teu monturo.

Amo a prantina silenciosa do teu fio de água, Descendo de quintais escusos Sem pressa, E se sumindo depressa na brecha de um velho cano.

Amo a avenca delicada que renasce $\mathrm{Na}$ frincha de teus muros empenados, E a plantinha desvalida, de caule mole

Que se defende, viceja e floresce No agasalho de tua sombra úmida e calada.

(Cora Coralina, 1989, p. 103)

Repleta de becos, vielas e permeada por uma paisagem que une a bucólica vila colonial ao emolduramento das serras verdejantes, a cidade de Goiás foi a primeira capital do estado de mesmo nome e surgiu a partir da exploração do ouro no interior do país empreendida pelos bandeirantes que colonizaram o Centro-Oeste brasileiro entre os séculos XVIII e XIX. Goiás foi sede administrativa até o ano de 1937, quando ocorreu a transferência oficial da capital estadual para Goiânial. Seu conjunto urbanístico e arquitetônico manteve as características da trama urbana original, incluindo a escala e a volumetria de suas edificações. Algumas de suas arquiteturas foram classificadas isoladamente pelo Instituto do Patrimônio Histórico e Artístico Nacional (Iphan) na década de 1950, e sua paisagem cultural foi tombada no ano de 1978, passando por ampliações em 2004. Em dezembro de 2001, Goiás foi reconhecida como Patrimônio Cultural Mundial pela Organização das Nações Unidas para a Educação, a Ciência e a Cultura (Unesco).

A paisagem da antiga Vila Boa de Goyaz ${ }^{2}$ apresenta relevante valor imagético, em especial no tocante ao seu patrimônio edificado. Através dos versos de Cora Coralina ${ }^{3}$,

A cidade de Goiás se localiza na bacia do rio Vermelho, a aproximadamente 130 quilômetros da capital Goiânia. Seu principal acesso se dá pela rodovia GO-070.

2 Vila Boa de Goyaz é o nome original da cidade de Goiás (GO). A terminologia "vila" corresponde à categoria administrativa do sistema de capitanias no período colonial. Na época, Goiás pertencia à Capitania de São Paulo. A região geográfica onde se fundou a vila, junto à cabeceira do rio Vermelho, era até então ocupada pelo grupo indígena Goyá, os goyazes, que deram nome à Vila. Essa é a origem do gentílico relacionado à cidade: "vilaboense".

3 A poetisa Cora Coralina (Cidade de Goiás, 1889 - Goiânia, 1985) foi uma das mais conhecidas cidadãs vilaboenses, sendo reverenciada também como uma das mais importantes escritoras brasileiras. Uma parcela significativa de seu trabalho literário faz alusão às ambiências e ao cotidiano da interiorana Goiás, que foi 
depreende-se a riqueza sinestésica da vivência nos variados ambientes de seu velho centro histórico. A umidade do rio Vermelho, o calor do sol, os sons, cores, odores e texturas da vila colonial são explorados pela poetisa, ilustrando atmosferas constitutivas de sua memória urbana e passíveis de serem experimentadas por quem se propõe a passear por suas vielas, becos e largos.

As tentativas de estabelecimento de uma relação teórica entre o ato de passear pelo território e a apreensão da paisagem e sua identidade remontam à virada do século XVIII para o XIX (LOPES, 2012, p. 45-46). Em 1802, no livro A arte de passear, Karl Gottlob Schelle já refletia sobre como as condições físicas de um determinado percurso repercutem diretamente nas experiências com as quais o caminhante tem contato. Segundo Lopes (2012, p. 46), Schelle ressalta:

[...] o valor das paisagens e da cultura do passeante como quesitos qualificadores dos passeios. Para ele, as caminhadas estão condicionadas aos lugares por onde se caminha e pela riqueza de espírito do passeante. A paisagem deixa de ser o resultado de um momento e passa a ser o fruto de um percurso, deixa de ser uma ideia e passa a ser uma experiência.

Schelle (2001) aborda o passeio como uma experiência de fruição estética pela paisagem. Dois pontos de suas considerações se mostram de grande interesse. Em primeiro lugar, a importância que a qualidade do percurso possui no incentivo à deriva, especialmente no que diz respeito à sua beleza natural. Em um segundo momento, ressalta-se a condicionante do indivíduo como fator determinante para a atividade e para a predisposição para apreciar a ambiência que o circunda.

Transpondo os dois séculos que separam a obra de Schelle das prerrogativas do caminhar na contemporaneidade, o deslocamento pedonal pela cidade não somente é entendido como opção de locomoção de baixo impacto ao meio ambiente (se comparado aos transportes motorizados), mas também como ação ativadora do espaço urbano, especialmente em relação à interação social. Para Sánchez e Campillo (2013, p. 40), caminhar pela cidade é estar disposto a conhecer, a colocar-se na expectativa do encontro e compartilhar experiências. Careri (2002), em Walkscapes, promove o entendimento do ato de caminhar como uma forma de habitar e construir simbolicamente a cidade, desenvolvendo diferentes atividades, dedicando tempo e olhares à percepção dos elementos que compõem a paisagem, explorando-a, contemplando-a, aventurando-se ludicamente, além de um ponto de vista apenas utilitário.

No atual contexto de incentivo à pedestrianização dos centros urbanos e humanização do espaço citadino, torna-se pertinente avaliar as condições que propiciam e incentivam o deslocamento a pé nas cidades. Gehl, em Cidades para pessoas, faz considerações que se assemelham ao já enunciado por Schelle (2001): "[...] a distância aceitável de caminhada é um conceito relativamente fluido" (GEHL, 2013, p. 121). Para o autor, a disposição para caminhar por trajetos maiores a pé depende em primeira

objeto, inclusive, de um de seus primeiros livros "Poemas dos becos de Goiás e estórias mais" (1975). 
instância da predisposição e das limiłações das pessoas. Em segundo lugar, a topografia, a qualidade do percurso, da paisagem e as condicionantes climáticas são alguns fatores que podem relativizar a adoção de uma distância ideal para o deslocamento a pé.

Borgogni (2013) classifica um meio urbano que apresenta infraestrutura, mobilidade, serviços esportivos, recreativos e ambiente sociável que facilita o uso do corpo na vida cotidiana como uma "cidade ativa", naturalmente mais saudável, inteligente, vital e segura. Dorato $(2014$, p. 2) acrescenta que a cidade ativa investe em políticas e ações visando à potencialização de oportunidades que consintam meios a todos os cidadãos para que se mantenham fisicamente ativos na vida cotidiana, de maneira integrada aos diversos ambientes urbanos. Essa perspectiva faz com que a infraestrutura, a integração espacial, os usos adequados, a forma e a qualidade das edificações e os contextos sociais incentivem o trânsito e a permanência no espaço urbano.

Ainda que a caminhada se converta ora em prática saudável, ora em absorção sensível da paisagem da cidade, Rey (2010, p. 109) destaca que, historicamente, "[...] a ação de atravessar o espaço nasce da necessidade natural de se deslocar a fim de encontrar alimentos e informações indispensáveis à sobrevivência". Essa relação é passível de releituras no cotidiano das cidades contemporâneas. No dia a dia, os cidadãos se deslocam em função de suas atividades laborais e necessidades de acesso a bens, serviços, atividades de lazer. Mesmo em uma cidade turística, são esses deslocamentos diários, ligados à dinâmica dos citadinos, que devem ser levados em consideração na configuração de uma cidade ativa. Portanto, pensar nos pressupostos que levam à ativação do espaço público e da paisagem pelas pessoas é de suma importância na pesquisa urbana contemporânea.

Fundamental à avaliação das cidades ativas é o conceito de 'caminhabilidade'. Conforme apontado por Ghidini (2011, p. 22), a caminhabilidade é definida como "[...] uma qualidade do lugar, o caminho que permite ao pedestre uma boa acessibilidade às diferentes partes da cidade [...]", sobretudo nos percursos desenvolvidos no dia a dia. Diante desse contexto, formulou-se a questão norteadora deste trabalho: no encontro entre a fruição estética da paisagem do centro histórico de Goiás e a vida cotidiana de seus cidadãos, quais são os níveis de caminhabilidade em percursos ordinários nessa área de especial interesse cultural e como estes se relacionam com a contemplação da paisagem formada pelo conjunto colonial? Baseado nesse enunciado, objetivou-se investigar trajetos cotidianos de moradores da cidade de Goiás levando em conta três perspectivas indissociáveis na análise urbana: as distâncias percorridas, a qualidade dos ambientes contemplados nos percursos e a paisagem. Como desdobramento da construção dos procedimentos metodológicos e dos resultados encontrados, promoveu-se uma breve discussão acerca da contribuição do estudo da qualidade paisagística e ambiental à análise da caminhabilidade, procurando superar avaliações segmentárias desta e explorar a sucessão de surpresas que o desvelar da paisagem através da caminhada proporciona ao transeunte, corroborando o mencionado por Cullen (2010, p. 10): "[...] uma cidade é antes do mais, uma ocorrência emocionante no meio ambiente". 


\section{REFERENCIAIS TEÓRICO E METODOLÓGICO}

A definição de qualidade talvez seja um dos mais complexos conceitos inerentes a qualquer processo de avaliação ambiental. Qualidade perante a que ou a quem são algumas das indagações que não raramente anunciam as inconsistências de diferentes processos de avaliação. Na raiz dos estudos de caminhabilidade está a enunciação de critérios de qualidade espacial com possíveis cenários de ocorrência no ambiente urbano e suas consequentes valorações.

Alguns trabalhos que se propõem a analisar a caminhabilidade em diferentes contextos de cidades brasileiras, como os de Barros, Martínez e Viegas (2015), Gonçalves et al. (2015) e Nanya e Sanches (2015), apresentam parâmetros de análise da qualidade em percursos urbanos desenvolvidos em uma série de categorias. Entre as categorias recorrentes nessas análises estão as que abordam desde questões dimensionais de infraestrutura urbana, passando por condicionantes de manutenção do espaço, incidência de obstáculos naturais ou construídos, exposição a intempéries, disposição de mobiliários urbanos, forma urbana, humanização, usos e paisagem envolvente. Assim, a avaliação da caminhabilidade envolve um espectro de temas que vão além do espaço caminhável, dialogam com a morfologia urbana, a paisagem e a ambiência em suas diversas interfaces sensoriais. A análise da caminhabilidade, desse modo, engloba duas dimensões de interesse nos estudos urbanos. Primeiramente, uma dimensão física: como se apresenta a infraestrutura do ambiente construído e que implicações traz para o indivíduo em sua locomoção. A segunda dimensão é a da percepção ambiental: como a paisagem se constrói e seu grau de ativação.

Historicamente a bibliografia clássica dedicada ao estudo das paisagens urbanas e da imagem da cidade vem pontuando confluências entre essas duas dimensões e justificando a inter-relação entre espaço, morfologia urbana, paisagem e ambiência. Ao estudar a fisionomia das cidades e os conjuntos de elementos que as compõem, Lynch (1997) argumentava que a paisagem urbana é construída a partir de cinco elementos: 1) vias; 2) pontos nodais; 3) marcos; 4) bairros; 5) agentes limítrofes ou barreiras lineares naturais ou construídas, promotoras de rupturas nas características de uso e ocupação do solo urbano. Tais elementos são recuperados por Panerai (2014), que enfatiza a forte relação da morfologia dos tecidos urbanos com a construção da paisagem da cidade. Outro autor cuja obra elenca mais detalhadamente os elementos compositivos da paisagem urbana é Cullen (2010), que aborda desde as intenções conceituais ligadas à morfologia do espaço, suas respectivas apreensões e características macropaisagísticas, até as interpretações sensíveis de seus detalhes. É interessante perceber como os critérios analíticos da caminhabilidade se pretendem generalistas e atravessam os pontos enunciados por esses três autores, exceto a questão mencionada a seguir.

O que é de extrema importância na relação do transitar pedonal com a apreensão da paisagem urbana, em um consenso entre Lynch (1997), Panerai (2014) e Cullen (2010), corresponde à compreensão de que o ato de percorrer caminhos faz com que as pessoas desvelem as paisagens urbanas. Esse 'desvelar' - que sugere uma ideia 
de gradação, de encadeamento - é essencial para o entendimento da contribuição desses referenciais clássicos ao método de análise da caminhabilidade. Ao dividir os percursos em trechos - segmentos de vias delimitados pelas calçadas -, a aferição dos níveis de caminhabilidade fornece dados estanques para cada fragmento. As transições paisagístico-ambientais não se mostram explícitas nesse âmbito analítico, em parte porque a paisagem é, como afirma Cullen (2010, p. 37), "o aqui e o além". Assim, uma categoria analítica como a de usos lindeiros ou de estado de manutenção de edificações em trechos estudados dificilmente esgota a experiência de imersão paisagística, o despertar sensível de um emolduramento da paisagem longínquo ou a surpresa da abertura de uma pequena viela em um largo. O fator óptico, tão bem analisado por Panerai (2014) e Cullen (2010), é um fenômeno de transições e rupturas, de gradações e surpresas - sobretudo, relacional e instigante: o que move o ser humano a prosseguir em uma caminhada está, em grande parte, na expectativa sobre o que está por vir. Assim, na dialética relação entre descobrir a paisagem por caminhar e caminhar para descobri-la, a análise paisagística parece ter valor diferenciado na avaliação da caminhabilidade, não podendo se restringir à abordagem setorial, mas ser vista na sua sequencialidade, no seu âmbito serial.

Tendo como base esse ideal, os procedimentos metodológicos de avaliação da caminhabilidade na cidade de Goiás, desenvolvidos neste trabalho, estruturam-se partindo de uma análise objetiva para uma abordagem qualitativa e sensível, que explora a relação dialética entre o transitar e a qualidade do ambiente construído. A área que sediou o estudo é o centro histórico de Goiás, onde foram elencados cinco percursos que simulam trajetos cotidianos a partir de um ponto inicial: uma casa escolhida estrategicamente em área com predominância do uso residencial. Os trajetos selecionados compreendem o acesso de menor distância aos exemplares próximos do referido ponto que possuem a seguinte natureza: uma escola, um espaço de lazer, um estabelecimento de saúde, um mercado e uma agência bancária. A localização desses exemplares e a demarcação dos trechos analisados se apresentam na figura 1.

Uma primeira avaliação objetiva, proposta neste estudo, parte desta indagação: o quão convidativas são ao deslocamento pedonal as distâncias desses estabelecimentos perante o referencial inicial? Conforme mencionado, não é possível afirmar com clareza um valor ideal para o desenvolvimento de uma caminhada, visto que as questões exógenas à própria dimensão do percurso se mostram preponderantes na decisão por percorrê-lo. Contudo, alguns autores que se dedicam a estudar estratégias de projeto urbano para cidades mais humanizadas enunciam algumas referências dimensionais favoráveis ao trajeto a pé. Gehl (2013, p. 121) afirma que "[...] boa parte das pessoas está disposta a percorrer cerca de 500 metros". Allen e Farr (2013, p. 126) também avaliam que $o$ atendimento das necessidades diárias a pé se torna mais conveniente e convidativo quando os destinos se desenvolvem de modo agrupado e a uma distância de cerca de 400 metros. Na ausência de um consenso sobre a distância ideal para caminhadas, tomando como ponto de partida o postulado desses autores, foi considerado como balizador para a análise dimensional um valor intermediário aos 
citados por eles. Desse modo, as distâncias dos percursos aqui analisados, medidas em base cartográfica por acesso remoto, foram consideradas inadequadas quando se apresentaram superiores à marca de 450 metros.

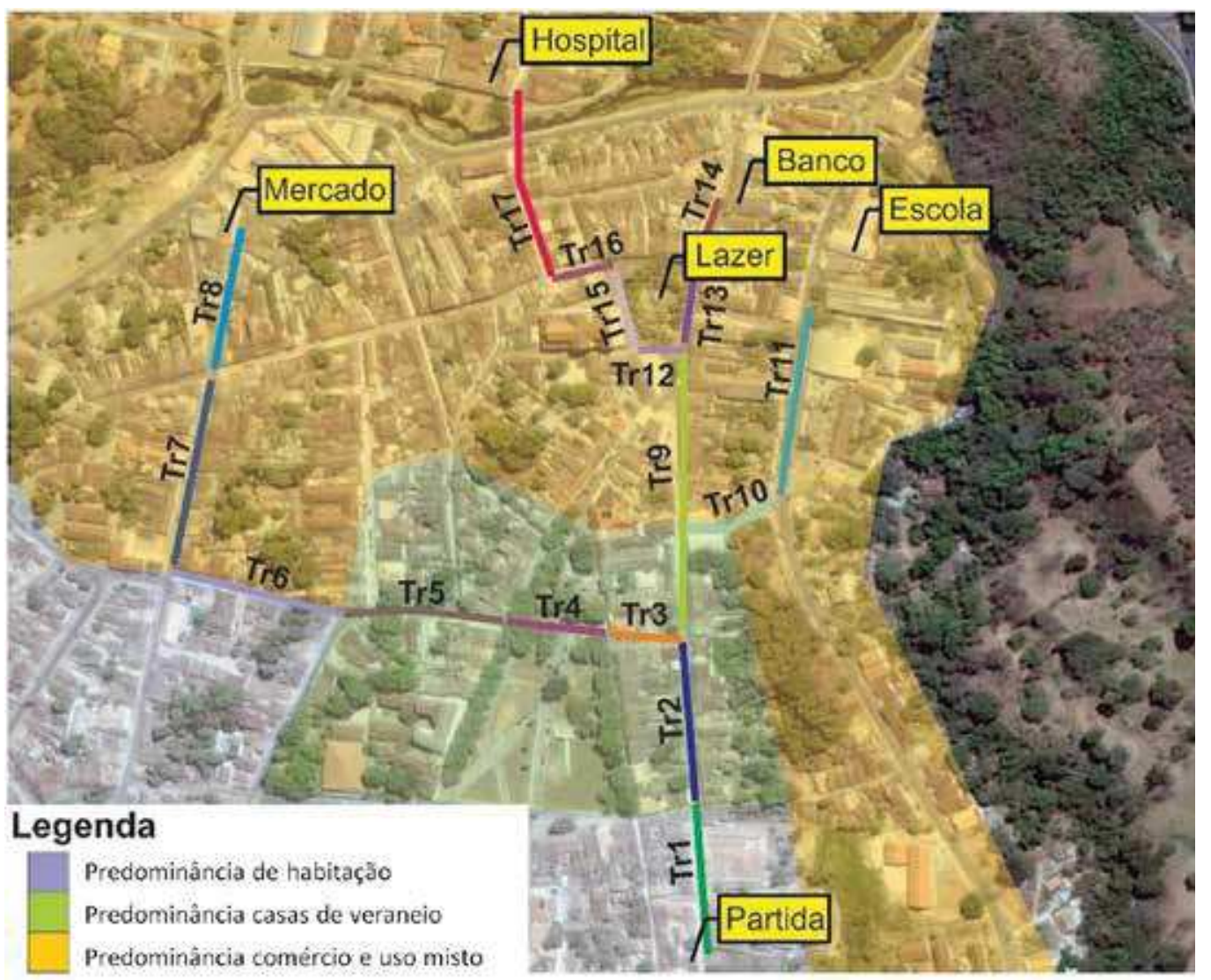

Figura 1 Percursos analisados na cidade de Goiás divididos em trechos.

Fonte: Mapa produzido sobre imagem Google Earth, 2016, pelos autores, 2017.

Uma segunda etapa analítica objetiva se detém nos trechos dos trajetos e respectivos níveis de caminhabilidade, considerando cada trecho como a porção de calçada localizada entre travessias. Para essa análise foram elencadas 11 categorias analíticas, que compreendem: a) largura da calçada; b) condições de pavimentação; c) obstáculos; d) proteção contra intempéries; e) mobiliário urbano de apoio; f) iluminação pública; g) usos lindeiros ao trajeto; h) segurança e orientação; i) qualidade da paisagem; i) vegetação; k) topografia. Cada categoria, apresentada em detalhe no quadro 1, é caracterizada em seis possíveis cenários, valorados entre 0 (zero) e 5 (cinco). A determinação dos cenários foi elaborada baseada nas condicionantes locais da cidade de Goiás.

método de cálculo para a geração dos índices de caminhabilidade por trecho é feito mediante o levantamento dos cenários encontrados em cada categoria, elaborando-se em seguida uma média aritmética que resulta em uma nota parcial para cada categoria em cada trecho. Já a nota total de cada trecho é obtida a partir da média aritmética das notas parciais na totalidade das categorias. Por fim, a nota 
total de caminhabilidade por percurso segue a mesma lógica de cálculo, envolvendo a média aritmética da totalidade de trechos que os compõem individualmente. Esses cálculos encerram a etapa de análise objetiva dos percursos com a geração dos níveis de caminhabilidade.

Quadro 1 Critérios de análise da qualidade

\begin{tabular}{|c|c|c|}
\hline Categoria & Cenário & Valor \\
\hline $\begin{array}{l}\text { Largura da } \\
\text { calçada }\end{array}$ & $\begin{array}{l}\text { Calçada ausente } \\
\text { Calçada com menos de } 0,75 \text { metro } \\
\text { Calçada entre 0,75 e 1,0 metro } \\
\text { Calçada entre 1,0 e 1,5 metro } \\
\text { Calçada entre 1,5 e 2,5 metros } \\
\text { Calçada com mais de 2,5 metros } \\
\end{array}$ & $\begin{array}{l}0 \\
1 \\
2 \\
3 \\
4 \\
5\end{array}$ \\
\hline $\begin{array}{l}\text { Condições de } \\
\text { pavimentação } \\
\text { Condições de } \\
\text { pavimentação } \\
\text { (cont.) }\end{array}$ & $\begin{array}{l}\text { Calçada sem pavimentação } \\
\text { Calçada com pavimentação parcial } \\
\text { Calçada com depressões } \\
\text { Calçada com pavimentação em bom estado } \\
\text { Calçada com pavimentação antiderrapante } \\
\text { Calçada com pavimentação antiderrapante, piso tátil de alerta e } \\
\text { direcional }\end{array}$ & $\begin{array}{l}0 \\
1 \\
2 \\
3 \\
4 \\
5\end{array}$ \\
\hline Obstáculos & $\begin{array}{l}\text { Obstáculo intransponível } \\
\text { Obstáculo contornável reduzindo a faixa de circulação a menos de } \\
0,6 \text { metro } \\
\text { Calçada com degrau maior que 0,18 metro ou com rampa } \\
\text { Calçada com degraus menores que 0,18 metro } \\
\text { Obstáculo contornável reduzindo a faixa de circulação a menos de } \\
\text { 1,20 metro } \\
\text { Calçada sem obstáculos }\end{array}$ & $\begin{array}{l}0 \\
1 \\
2 \\
3 \\
4 \\
5\end{array}$ \\
\hline $\begin{array}{l}\text { Proteção contra } \\
\text { intempéries }\end{array}$ & $\begin{array}{l}\text { Proteção inexistente } \\
\text { Cobertura pontual } \\
\text { Cobertura em } 25 \% \text { da calçada } \\
\text { Cobertura em } 50 \% \text { da calçada } \\
\text { Cobertura em } 75 \% \text { da calçada } \\
\text { Cobertura total na calçada }\end{array}$ & $\begin{array}{l}0 \\
1 \\
2 \\
3 \\
4 \\
5\end{array}$ \\
\hline $\begin{array}{l}\text { Mobiliário urbano } \\
\text { de apoio }\end{array}$ & $\begin{array}{l}\text { Inexistência de mobiliário urbano de apoio } \\
\text { Calçada com um item de mobiliário urbano, mas não de } \\
\text { permanência, danificado } \\
\text { Calçada com um item de mobiliário urbano, mas não de permanência } \\
\text { Calçada com um item de mobiliário urbano de permanência } \\
\text { danificado } \\
\text { Calçada com um item de mobiliário urbano de permanência em } \\
\text { bom estado } \\
\text { Calçada com mais de um item de mobiliário urbano de permanência } \\
\text { em bom estado }\end{array}$ & $\begin{array}{l}0 \\
1 \\
2 \\
3 \\
4 \\
5\end{array}$ \\
\hline $\begin{array}{l}\text { lluminação } \\
\text { pública }\end{array}$ & $\begin{array}{l}\text { Inexistência de iluminação pública } \\
\text { lluminação pública para automóveis com pontos de obscurecência } \\
\text { lluminação pública para automóveis em bom estado de conservação } \\
\text { lluminação pedonal com pontos de obscurecência } \\
\text { lluminação pedonal em intervalos regulares em bom estado de } \\
\text { conservação } \\
\text { lluminação para automóveis e pedonal em bom estado de } \\
\text { conservação }\end{array}$ & $\begin{array}{l}0 \\
1 \\
2 \\
3 \\
4 \\
5\end{array}$ \\
\hline
\end{tabular}




\begin{tabular}{|c|c|c|}
\hline $\begin{array}{l}\text { Usos lindeiros ao } \\
\text { trajeto }\end{array}$ & $\begin{array}{l}\text { Muros e terrenos baldios } \\
\text { Uso exclusivamente residencial } \\
\text { Uso exclusivamente comercial e institucional } \\
\text { Uso misto com pouca movimentação nas calçadas } \\
\text { Uso misto com movimentação moderada nas calçadas } \\
\text { Uso misto com grande movimentação nas calçadas }\end{array}$ & $\begin{array}{l}0 \\
1 \\
2 \\
3 \\
4 \\
5\end{array}$ \\
\hline $\begin{array}{l}\text { Segurança e } \\
\text { orientação } \\
\text { Segurança e } \\
\text { orientação } \\
\text { (cont.) }\end{array}$ & $\begin{array}{l}\text { Ausência de faixas de pedestre e sinalização } \\
\text { Faixas de pedestre e sinalização em mav estado de conservação } \\
\text { Faixas de pedestre com obstrução de visão } \\
\text { Faixas de pedestre em bom estado de conservação e sem rampas } \\
\text { Faixas de pedestre em bom estado de conservação e com rampas } \\
\text { Faixas de pedestres elevadas e com boa sinalização }\end{array}$ & $\begin{array}{l}0 \\
1 \\
2 \\
3 \\
4 \\
5\end{array}$ \\
\hline $\begin{array}{l}\text { Qualidade da } \\
\text { paisagem }\end{array}$ & $\begin{array}{l}\text { Construções sem diálogo com o espaço público } \\
\text { Construções em mau estado de conservação e/ou abandonadas } \\
\text { Construções parcialmente em diálogo com o espaço público } \\
\text { Construções em bom estado de conservação e com aberturas } \\
\text { fechadas } \\
\text { Construções em bom estado de conservação e com aberturas } \\
\text { abertas } \\
\text { Construções com grandes aberturas para o espaço público ou com } \\
\text { áreas ajardinadas }\end{array}$ & $\begin{array}{l}0 \\
1 \\
2 \\
3\end{array}$ \\
\hline Vegetação & $\begin{array}{l}\text { Sem vegetação } \\
\text { Vegetação insuficiente } \\
\text { Vegetação de forração pontual } \\
\text { Vegetação arbustiva pontual } \\
\text { Vegetação arbórea em parte do trecho } \\
\text { Vegetação arbórea ao longo do trecho } \\
\end{array}$ & $\begin{array}{l}0 \\
1 \\
2 \\
3 \\
4 \\
5\end{array}$ \\
\hline Topografia & $\begin{array}{l}\text { Inclinação maior que } 20 \% \\
\text { Inclinação entre } 10 \% \text { e } 20 \% \\
\text { Inclinação entre } 8 \% \text { e } 10 \% \\
\text { Inclinação entre } 5 \% \text { e } 8 \% \\
\text { Inclinação entre } 1 \% \text { e } 5 \% \\
\text { Plano } \\
\end{array}$ & $\begin{array}{l}0 \\
1 \\
2 \\
3 \\
4 \\
5\end{array}$ \\
\hline
\end{tabular}

Fonte: Produzido pelos autores, 2016.

Para além da dimensão objetiva, estudos já empreendidos sobre a motivação para - caminhar pela qualidade ambiental e paisagística - bem como a noção de desenvolvimento progressivo da paisagem e a revisão bibliográfica apresentada - geram para este trabalho questões adicionais que requerem análises qualitativa e perceptual que se aproximem do ponto de vista, das sensações e emoções do observador no espaço. Para tanto, além da avaliação disposta na planilha de critérios de qualidade espacial com base na caminhabilidade, apresentada no quadro 1, o estudo se ocupou de registrar as visões obtidas a partir do transeunte, documentando os percursos por meio de fotografias em visão serial. Nesse processo, registra-se uma sucessão de pontos de vista na qual são documentadas a imagem existente e a imagem emergente no processo de deslocamento (CULLEN, 2010). Mais além, este estudo considera o observador como sujeito de uma experiência desenvolvida em sua interação com o ambiente e demais usuários, passível de certo grau de subjetividade. Nesse sentido, serve-se da abordagem experiencial do 'pesquisador-usuário' do espaço que qualifica os dados objetivos e descreve os aspectos sensíveis do caminhar em meio à paisagem, 
levando em consideração o exposto por Latour (2001, p. 338): o mundo apreendido exteriormente é observado, sentido e assimilado por uma mente interna ao indivíduo, da qual parte toda a semântica conferida ao ambiente em que se encontra.

\section{CAMINHABILIDADE E PAISAGEM: PERCORRENDO AS VIELAS DE GOIÁS}

Caminhar pela cidade pode ser uma atividade prazerosa, mas alguns fatores dimensionais do percurso tornam esse hábito mais ou menos convidativo. Na análise das distâncias dos percursos que simulam trajetos cotidianos a partir de um ponto inicial, ilustrada na figura 2, evidencia-se que apenas o acesso ao lazer (460 metros) se encontra dentro das distâncias ideais ao deslocamento pedonal estabelecidas por Gehl (2015) - e os demais acessos ficam fora das distâncias que favorecem a caminhabilidade consideradas neste trabalho.

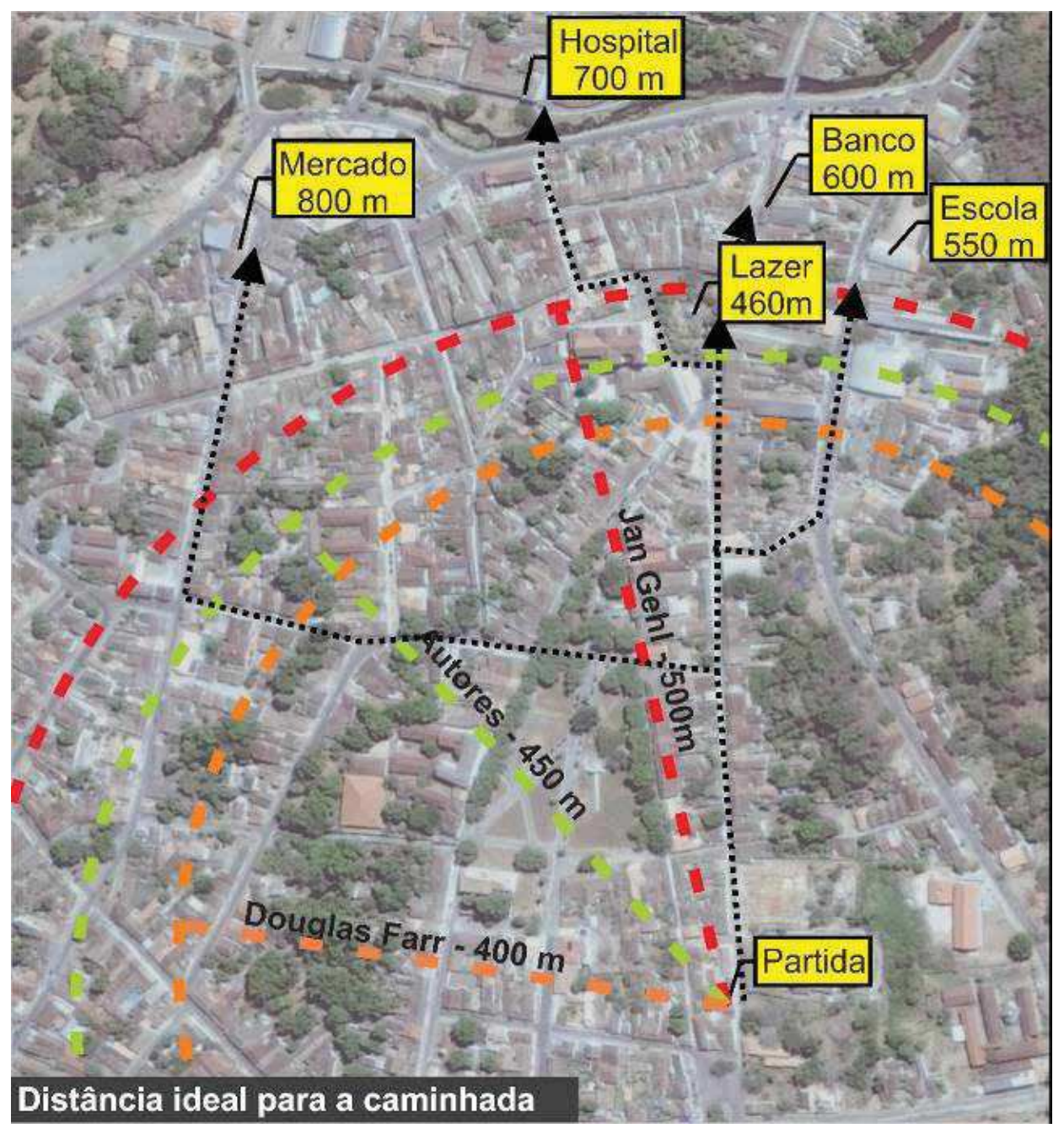

Figura 2 Distâncias de caminhada.

Fonte: Mapa produzido sobre imagem Google Earth, 2016, pelos autores, 2017. 
O resultado da primeira parte da pesquisa demonstra de forma simplificada que as distâncias percorridas para locais de usos cotidianos no centro histórico da cidade de Goiás tendem a menor força convidativa à caminhabilidade e um possível convite para deslocamento motorizado. Esse é um fator pertinente, mas não preponderante no intuito do deslocamento, sendo necessário o aprofundamento nas qualidades espaciais desses percursos.

Ao observar os resultados dispostos nos quadros 2 a 6, desenvolvidos nos tópicos que seguem, percebe-se que os percursos apresentam níveis de caminhabilidade consideravelmente insuficientes, em que as precariedades do espaço e sua ativação se tornam latentes na disposição dos resultados em cada quadro, organizada por trechos. Trajetos como o percurso entre a residência e o mercado, ou a escola e o hospital apresentam condicionantes e significações próprias para o indivíduo, como suas apreensões, medos e dores (em relação ao hospital), ou a necessidade do deslocamento com mochilas, bolsas e sacolas (referente ao mercado e à escola). Contudo, a análise descritiva evidencia os potenciais que a forma urbana e a constituição da trama colonial promovem na diversidade da paisagem e na surpresa do usuário durante sua caminhada. Como exemplos mostram-se os percursos da residência ao banco ou ao mercado - que contêm o trajeto ao lazer -, possuidores de dinâmicas paisagísticas variadas e surpresas que o traçado urbano faz emergir no caminhar.

Quadro 2 Percurso residência-mercado: notas de caminhabilidade

\begin{tabular}{|c|c|c|c|}
\hline Categoria & $\begin{array}{c}\text { Média aritmética } \\
\text { dos trechos } \\
1,2,3,4,5,6,7 \text { e } 8\end{array}$ & Categoria & $\begin{array}{c}\text { Média aritmética } \\
\text { dos trechos } \\
1,2,3,4,5,6,7 \text { e } 8\end{array}$ \\
\hline Largura da calçada & 1,44 & $\begin{array}{l}\text { Usos lindeiros } \\
\text { ao trajeto }\end{array}$ & 1,98 \\
\hline Condições de pavimentação & 1,83 & $\begin{array}{l}\text { Segurança e } \\
\text { orientação }\end{array}$ & 0,38 \\
\hline Obstáculos & 1,06 & $\begin{array}{c}\text { Qualidade da } \\
\text { paisagem }\end{array}$ & 2,84 \\
\hline Proteção contra intempéries & 0,5 & Vegetação & 0,44 \\
\hline Mobiliário urbano de apoio & 0 & Topografia & 3,12 \\
\hline Iluminação pública & 3 & $\begin{array}{l}\text { Média Final } \\
\text { do Percurso }\end{array}$ & 1,51 \\
\hline
\end{tabular}

Fonte: Produzido pelos autores, 2016.

Partindo da residência (figura 3-A), o pedestre caminha por ruas estreitas, com área carroçável de pedras irregulares que comportam dois veículos em sua largura. O sentido de vizinhança se fortalece com a presença de moradores ocasionalmente trafegando pelas ruas ou simplesmente sentados à porta de suas casas (figura 3-B). O observador encontra-se ladeado pela atmosfera colonial do casario contínuo de 
um pavimento, ritmado pelas sequências dos vãos de portas e janelas de esquadrias de madeira e verga reta (em sua grande maioria), apenas interrompidas por trechos de empenas cegas que fazem fechamento de alguns lotes. Não há continuidade nas calçadas, cuja pavimentação não se apresenta em bom estado de conservação - e que não raramente são interrompidas por pequenas escadas ou outros obstáculos (figura 3-C). Também não há quaisquer tipos de proteção contra intempéries ou mobiliários urbanos de apoio, mesmo se tratando de trecho em aclive.
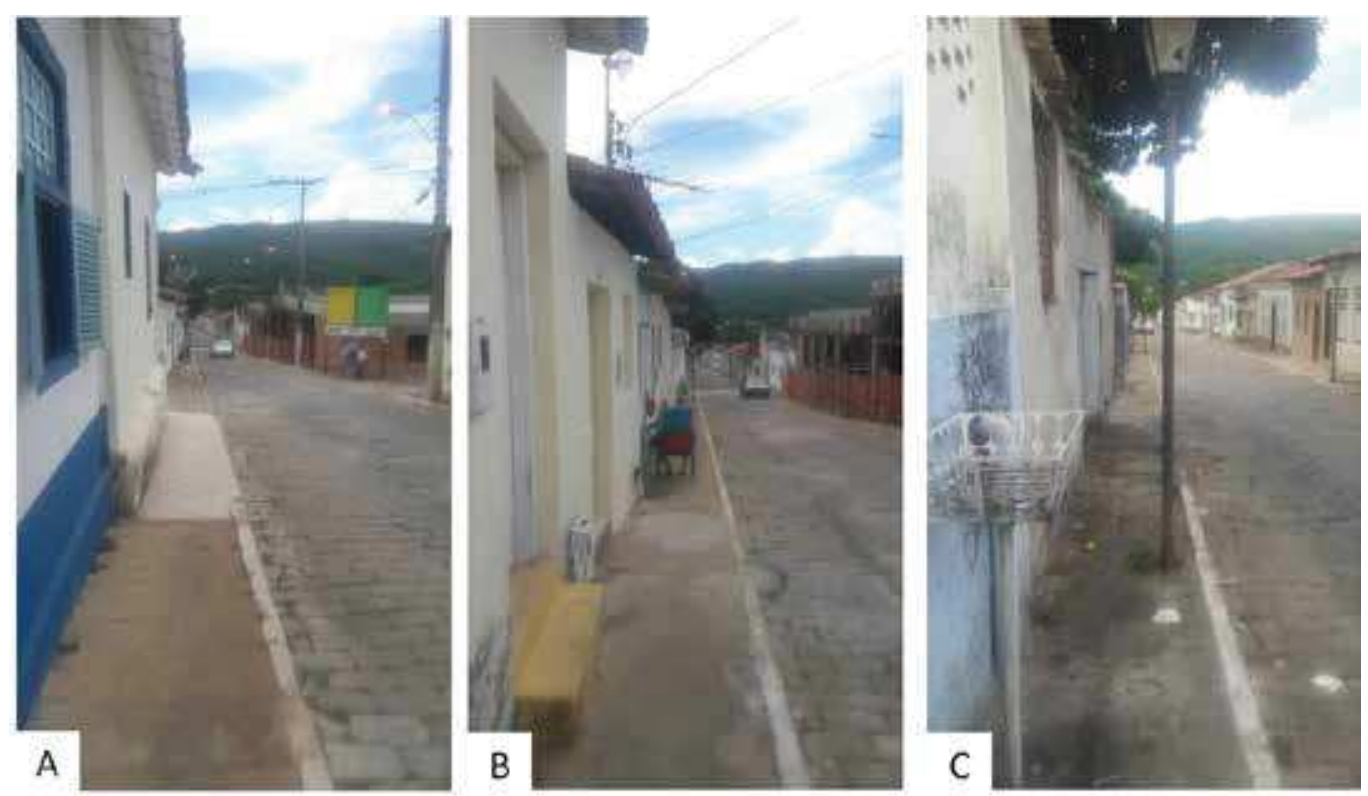

Figuras 3-A, 3-B e 3-C Imagens dos trechos iniciais do percurso residência-mercado. Fotos: Carina Cardoso, 2016.

Ao dobrar a esquina e percorrer o trecho 3 (figura 4-A), o sentido de acolhimento que a proximidade das construções promove se transforma num deslumbre ao chegar à área cortada pelos trechos 4 e 5, correspondentes à praça do Chafariz (figura 4-B). Aí, ao contrário dos trechos 1 e 2 e dos trechos que se seguirão, há grande amplitude visual e vegetação abundante. Uma extensa área verde, com vegetação rasteira e arbustiva e maior sombreamento, torna-se um ambiente convidativo à fauna. Desse modo, o transeunte tem contato com os sons advindos das maritacas e tucanos que ali sobrevoam, sobretudo ao cair da tarde.

A boa qualidade ambiental, especialmente relacionada ao sombreamento e às áreas livres, também atrai crianças, que jogam bola nos extensos canteiros gramados, ocasionalmente ocupados por rodas de capoeira que auxiliam na construção da identidade do lugar não somente por permearem a paisagem, mas também por marcarem a ambiência através do som do berimbau. Não há, nesse ponto, separação entre calçadas e faixas de rolamento para automóveis. No entanto, a pavimentação de pedras oferece certa regularidade (figura 4-B), e vias laterais mais estreitas e mais próximas às edificações subentendem tráfego mais lento. 

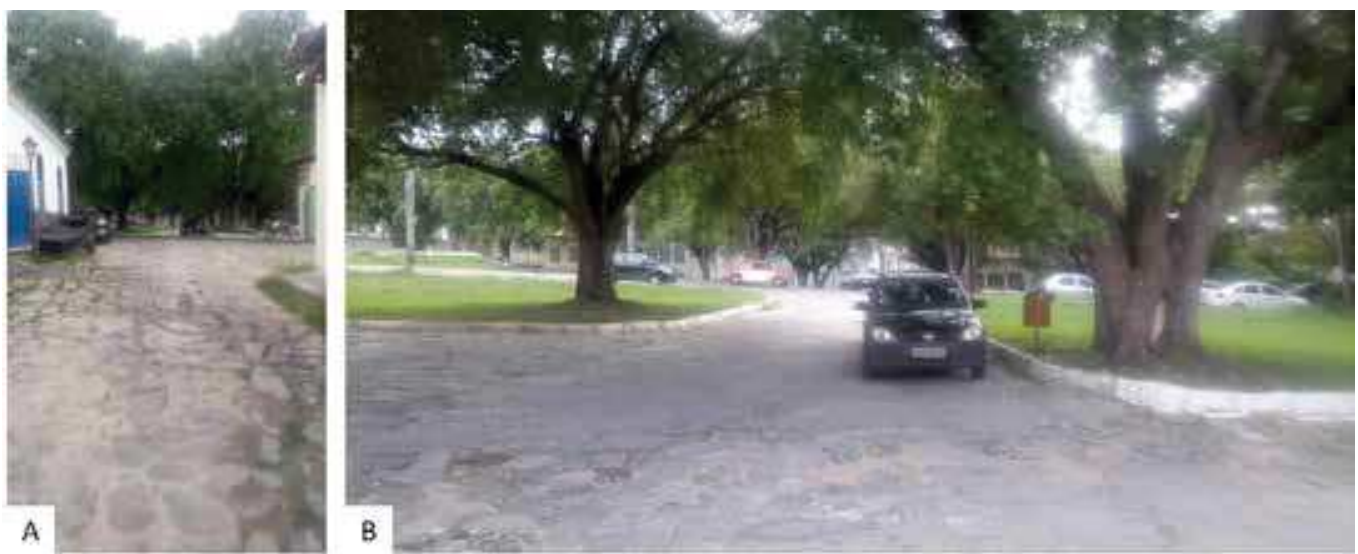

Figuras 4-A e 4-B Imagens dos trechos de aproximação e chegada à praça do Chafariz. Fotos: Carina Cardoso, 2016.

A harmonia promovida pela praça se evanesce à medida que se avança em direção aos trechos finais (figura 5-A). Ainda que permanecendo em traçado plano até o fim do trecho 6, a paisagem aos poucos vai se tornando menos atraente. Há diminuição das construções coloniais, redução da vegetação e, mais além, o cabeamento de energia elétrica passa a ser distribuído no espaço aéreo. A caixa das ruas nesse trecho se torna mais larga, repercutindo em um tráfego a maiores velocidades, que requerem a atenção do pedestre. Não existem sinalizações e faixas de travessia no percurso todo. Nas calçadas estreitas, quando não interrompidas ou com obstáculos, já não se vê tanto a presença de moradores (figura 5-B). Aqui o passo vai pouco a pouco se tornando mais apressado, parcialmente coberto pelas pontuais coberturas ou marquises dos pontos comerciais que paulatinamente começam a surgir, intensificando-se.
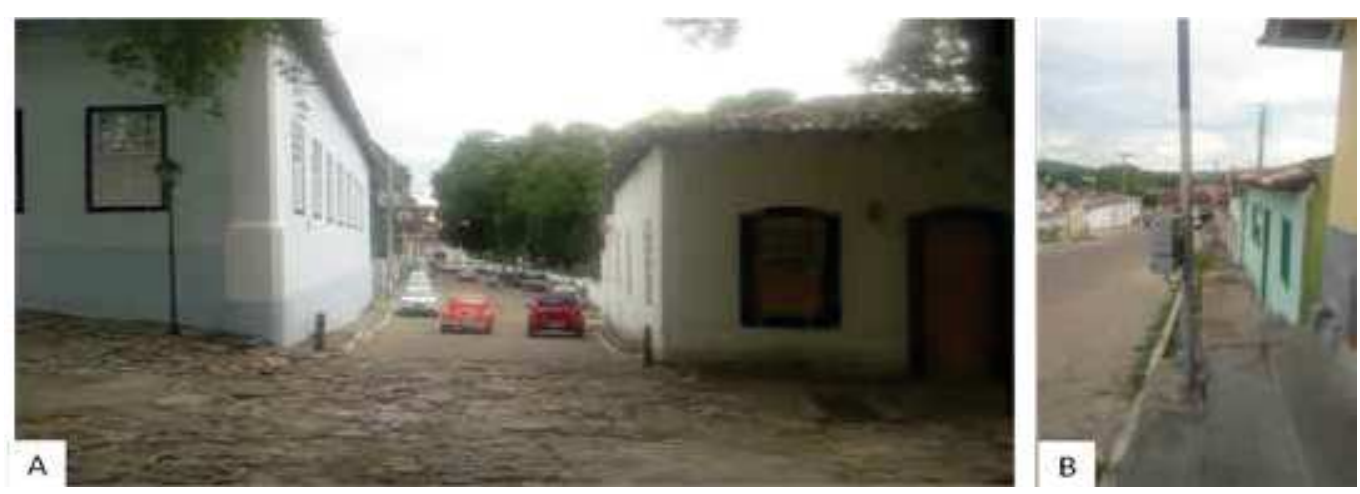

Figuras 5-A e 5-B Trechos entre o trajeto da praça do Chafariz à rua do mercado. Fotos: Carina Cardoso, 2016.

Até chegar aos trechos 7 e 8, essa ambiência se consolida: trânsito intenso, andar mais apressado do transeunte, edificações de uso misto em gabaritos maiores do que na região do conjunto colonial - que se relacionam pouco com o espaço público devido à redução de aberturas no nível dos olhos do observador. Sem vegetação e 
mobiliário urbano de apoio, tampouco calçadas com boa pavimentação ou livres de obstáculos, esse trecho ainda apresenta maior movimentação de pedestres por sua natureza comercial (figura 6-A).
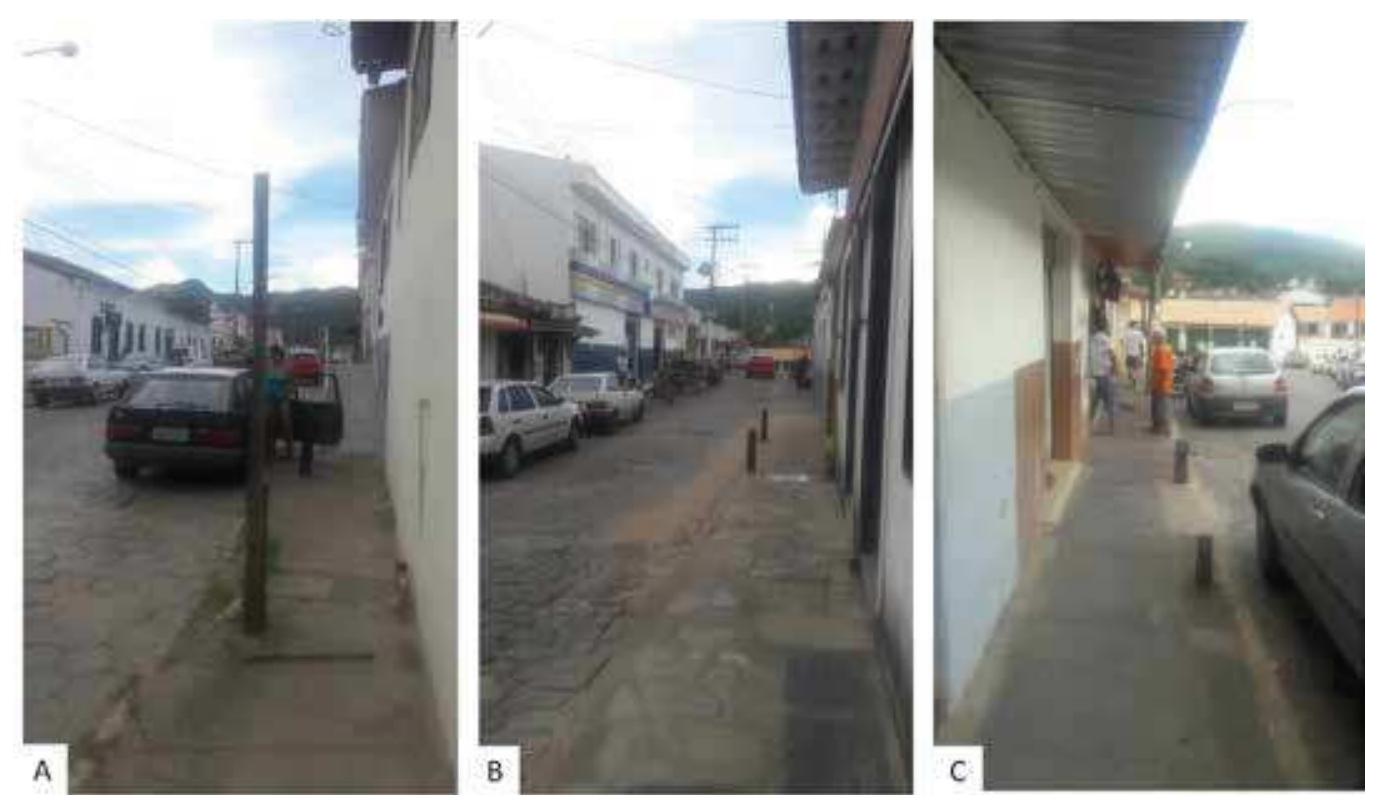

Figuras 6-A, 6-B e 6-C Trechos da rua do mercado.

Fotos: Carina Cardoso, 2016.

A finalização do percurso ocorre com a chegada ao mercado, que se encontra imerso em uma zona comercial dotada de edificações que não ultrapassam os dois pavimentos e de um apelo visual próprio de atividades de consumo (figuras 6-B e 6-C). Aqui se mantém o fio de água silencioso apontado por Coralina (1989), que desce dos quintais escusos, mas em grande parte oculto pelas placas e letreiros de uma das ruas mais movimentadas da cidade.

Sair da residência e deslocar-se até a escola mais próxima propõe ao pedestre experimentar a dualidade da ambiência na cidade de Goiás. Primeiramente, os trechos iniciais - 1, 2 e parte do 9 - correspondem ao traçado histórico da cidade, de ruas estreitas com pedras irregulares, calçadas com pavimentação inadequada e mal conservada, repletas de obstáculos, interrupções e nenhuma condicionante de conforto, como proteção contra intempéries, vegetação ou mobiliário urbano de apoio. Ainda assim essa região se torna mais aprazível ao pedestre pela relação de vizinhança, pela escala humana imposta e pela proximidade do casario histórico, que admite raros exemplares com dois pavimentos (figuras 3-A, 3-B e 3-C).

Ao converter à direita no trecho 10, o percurso é ladeado pelos muros cegos de uma construção abandonada, desenvolvendo-se como um beco plano, estreito e escuro (figura 7-A). Não há relação com a paisagem construída, o que faz com que o único objetivo do transeunte nesse trecho seja chegar ao outro lado. Não há movimento nas calçadas e a ambiência do local é pouco convidativa ao trânsito. Ao final do trecho, 
um quintal fronteiriço do lote de esquina abriga um espaço cultural a céu aberto, mas não há calçamento adequado que oriente a visita, nem qualquer tipo de iluminação especial ou tratamento da paisagem. Outra vez, imputa-se a sensação de dever seguir andando (figura 7-B).

Quadro 3 Percurso residência-escola: notas de caminhabilidade

\begin{tabular}{|c|c|c|c|}
\hline Categoria & $\begin{array}{c}\text { Média aritmética dos } \\
\text { trechos } \\
1,2,9,10 \text { e } 11\end{array}$ & Categoria & $\begin{array}{c}\text { Média aritmética dos } \\
\text { trechos } \\
1,2,9,10 \text { e } 11\end{array}$ \\
\hline Largura da calçada & 1,2 & $\begin{array}{l}\text { Usos lindeiros } \\
\text { ao trajeto }\end{array}$ & 1,97 \\
\hline Condições de pavimentação & 1,67 & $\begin{array}{l}\text { Segurança e } \\
\text { orientação }\end{array}$ & 0,2 \\
\hline Obstáculos & 1,2 & $\begin{array}{c}\text { Qualidade da } \\
\text { paisagem }\end{array}$ & 2,14 \\
\hline Proteção contra intempéries & 0 & Vegetação & 0,1 \\
\hline Mobiliário urbano de apoio & 0 & Topografia & 2,6 \\
\hline Iluminação pública & 2,8 & $\begin{array}{l}\text { Média Final } \\
\text { do Percurso }\end{array}$ & 1,26 \\
\hline
\end{tabular}

Fonte: Produzido pelos autores, 2016.

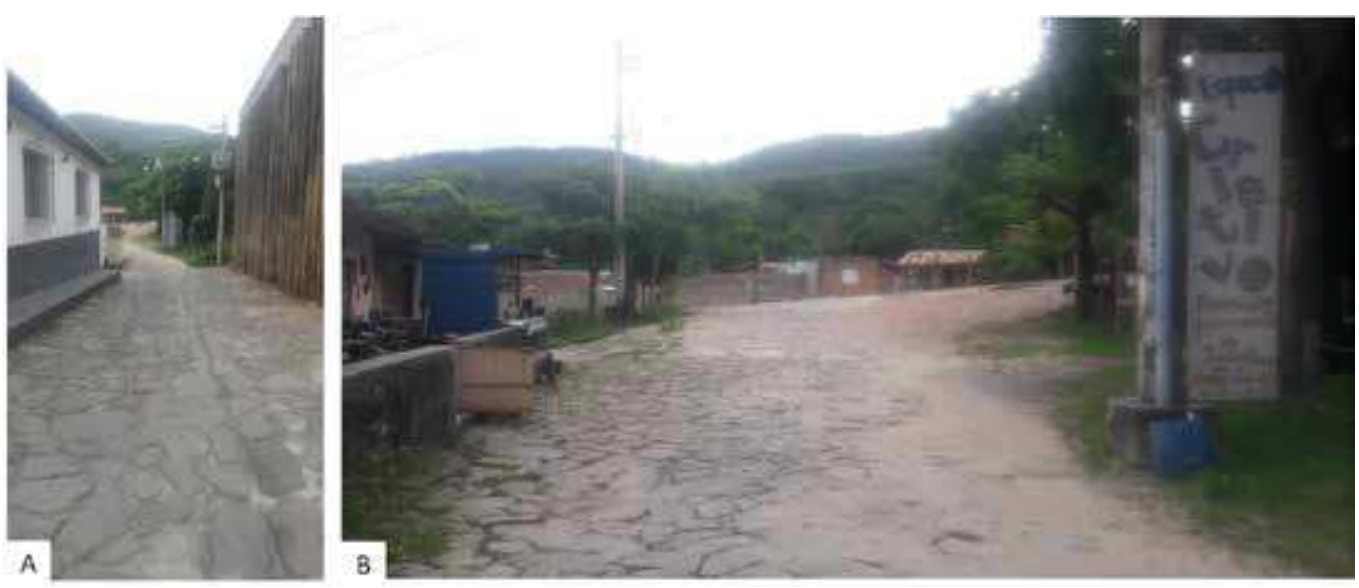

Figuras 7-A e 7-B Trechos entre a rua da residência e a rua da escola. Fotos: Carina Cardoso, 2016.

A continuação da deriva conduz à escola. Nesse trecho final, o 11, a paisagem é oposta ao que se vê na tipologia histórica da malha tradicional. A diferenciação não diz respeito à qualidade do ambiente, mas sim às características morfológicas da trama urbana: uma pista ampla, asfaltada, com calçada em ambos lados, onde se encontram lotes maiores, ocupados em sua maioria por galpões, além da própria escola (figura 8-A). No tocante à qualidade da paisagem, as calçadas não são largas, mas apresentam maior continuidade e menos obstáculos. Não há proteção contra intempéries, 
vegetação ou mobiliário urbano de apoio, mas há um fluxo moderado de pessoas em trânsito. Diferentemente das áreas históricas mais tradicionais - como as indicadas pelos trechos 1, 2 e 9 -, essas pessoas não são moradoras, mas sim passantes.

É necessário atenção, pois a via em aclive tem um fluxo grande de veículos, inclusive de grande porte como ônibus e caminhões, e a sinalização é insuficiente, assim como a vegetação. $\bigcirc$ fato de se apresentar como uma rua asfaltada também possibilita um deslocamento automotivo a velocidades maiores. A percepção é a de estar passando por um local onde há pouco diálogo das edificações com a rua, por seus muros e esquadrias cerradas, além de um parcelamento do solo que gera menor adensamento construtivo e, consequentemente, demográfico (figura 8-B).
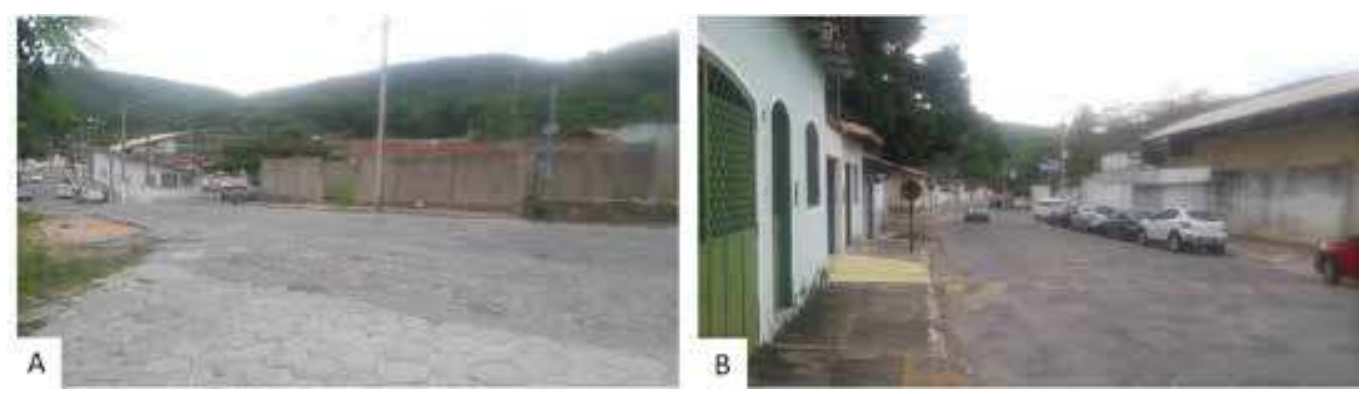

Figuras 8-A e 8-B Trechos finais de chegada à escola. Fotos: Carina Cardoso, 2016.

Quadro 4 Percurso residência-lazer: notas de caminhabilidade

\begin{tabular}{l|c|c|c}
\hline Categoria & $\begin{array}{c}\text { Média aritmética } \\
\text { dos trechos } \\
1,2,9 \text { e 12 }\end{array}$ & Categoria & $\begin{array}{c}\text { Média aritmética } \\
\text { dos trechos } \\
1,2,9 \text { e 12 }\end{array}$ \\
\hline Largura da calçada & 1,13 & Usos lindeiros ao trajeto & 2,83 \\
\hline Condições de pavimentação & 1,46 & Segurança e orientação & 0 \\
\hline Obstáculos & 1,5 & Qualidade da paisagem & 2,84 \\
\hline Proteção contra intempéries & 0,38 & Vegetação & 0,75 \\
\hline Mobiliário urbano de apoio & 1,25 & Topografia & 2,25 \\
\hline Iluminação pública & 3,75 & Média Final do Percurso & 1,65 \\
\hline
\end{tabular}

Fonte: Produzido pelos autores, 2016.

Algumas cidades são entusiasticamente percorridas a pé mesmo apresentando baixos índices de caminhabilidade, com relevos extremamente acidentados, ruas estreitas, ausência de calçadas, inexistência de faixa de pedestres, pavimentação desigual e insuficiência de parâmetros de acessibilidade. Segundo Speck (2012), isso se deve em grande parte ao traçado urbano, que pode se portar como fator dinamizador da paisagem. Os percursos residência-lazer e residência-banco atestam um quadro semelhante a esse. 
Quadro 5 Percurso residência-banco: notas de caminhabilidade

\begin{tabular}{c|c|c|c}
\hline Categoria & $\begin{array}{c}\text { Média aritmética } \\
\text { dos trechos } \\
1,2,9,13 \text { e } 14\end{array}$ & Categoria & $\begin{array}{c}\text { Média aritmética } \\
\text { dos trechos } \\
1,2,9 \text { e 12 }\end{array}$ \\
\hline Largura da calçada & 1,5 & Usos lindeiros ao trajeto & 3,27 \\
\hline Condições de pavimentação & 1,67 & Segurança e orientação & 0 \\
\hline Obstáculos & 1,8 & Qualidade da paisagem & 3,07 \\
\hline Proteção contra intempéries & 0,3 & Vegetação & 0,6 \\
\hline Mobiliário urbano de apoio & 1 & Topografia & 2,6 \\
\hline Iluminação pública & 3,8 & Média Final do Percurso & 1,78 \\
\hline
\end{tabular}

Fonte: Produzido pelos autores, 2016.

A pavimentação das vias carroçáveis, estreitas, é em pedra irregular, o que pressupõe tráfego um pouco mais lento. Assim, ao longo dos trechos 1, 2 e 9, predomina a contemplação da paisagem delineada pelo casario histórico, majoritariamente de edificações de um pavimento (figuras 3-A, 3-B e 3-C). A ambiência por ela produzida conta com uma ritmada disposição de fenestrações a partir da tipologia de portas e janelas coloniais intercaladas por muros cegos que geram fechamento de lotes voltados para outras vias. Também compõem o enquadramento da paisagem os beirais prolongados de telhas cerâmicas - que em dias de chuva criam uma cortina de água que desce sobre a calçada. O caminhar é lento para o morador que conhece os entraves em seu passeio, guardando também a precaução para conter a velocidade e vencer o desnível existente (figura 9-A). Na sonoridade do espaço é marcante o som ocasional do badalar dos sinos da igreja, ao final do trecho 9 (figura 9-B).
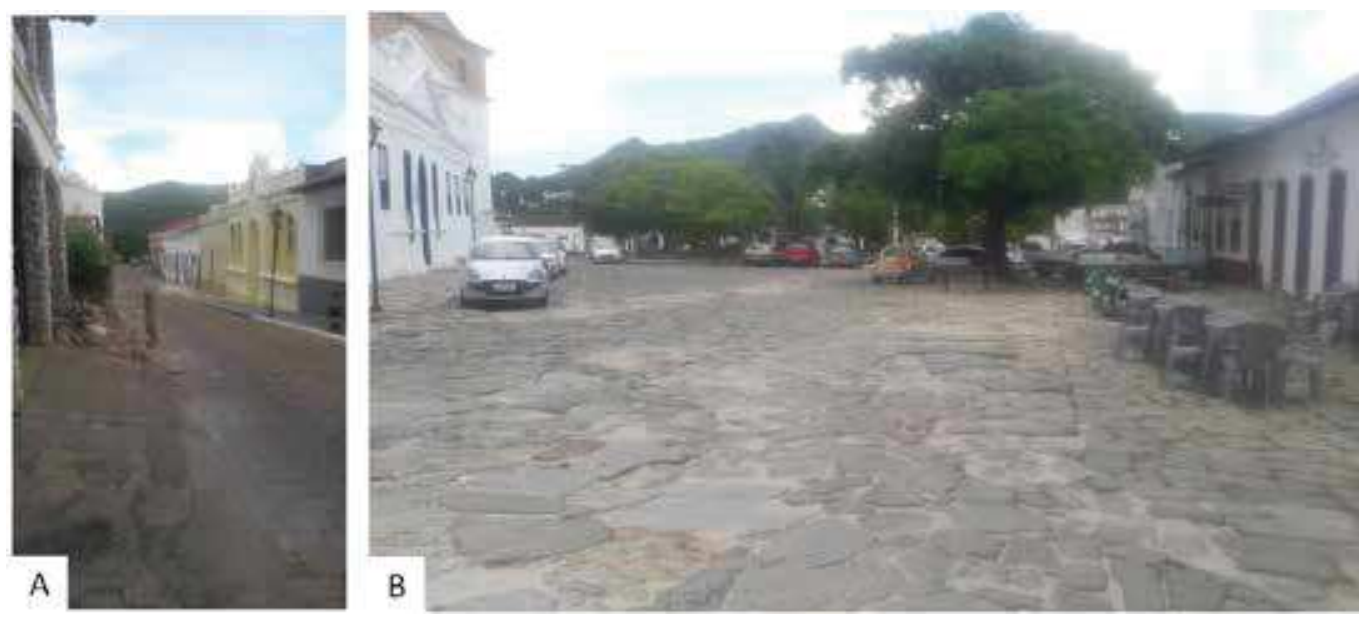

Figuras 9-A e 9-B A abertura da rua ao largo da praça. Fotos: Carina Cardoso, 2016. 
Aí se vê o desvelar de um ambiente bucólico e agregador: a principal praça da cidade - a praça do Coreto - inaugura uma sensação de amplitude no percurso (figura 10-A), abrindo a perspectiva urbana em si com um generoso espaço praticamente plano, bem equipado com mobiliário urbano de apoio, vegetação em diferentes escalas - que promovem áreas sombreadas, porém sem qualquer proteção contra chuvas -, iluminação pública suficiente e calçamento em bom estado de conservação (figura 10-B). A praça é um dos principais pontos de lazer da cidade e, de fato, promove a interação social em diversos níveis, permitindo a seus ocupantes a diversidade do uso e do olhar, seja com a prática de brincadeiras infantis, rodas de capoeira, performances artísticas, bate papo tomando um sorvete, ou o singelo e enriquecedor contemplar da paisagem cultural que a cerca. Interessante é perceber, também, que o principal espaço de lazer da cidade é ladeado por edificações de uso misto: residências, em sua minoria, dividem espaço com comércio e instituições públicas e religiosas. A praça, em parte contemplada pelo trecho 12 e em parte pelo 13, apresenta sempre grande movimentação de pedestres.
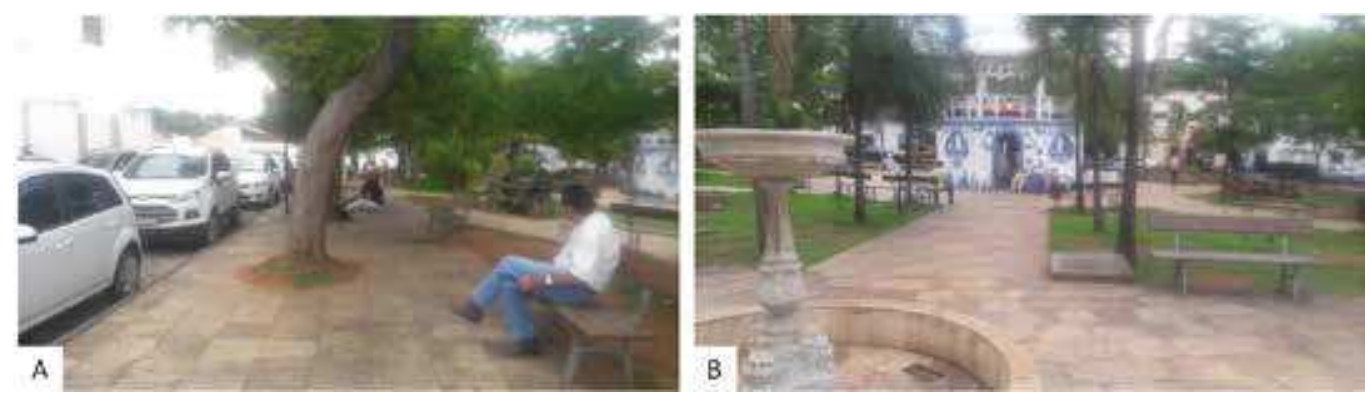

Figuras 10-A e 10-B Praça do Coreto.

Fotos: Carina Cardoso, 2016.

Seguindo pelo trecho 13, prossegue-se no percurso ao banco e, justamente em sua extremidade, na junção com o trecho 14, tem-se um dos mais belos panoramas de Goiás: o declive da rua de pedras, com suas calçadas estreitas e irregulares, tem como ponto focal a igreja do Rosário, antecedida pela ponte onde se encontra o museu Casa de Cora Coralina (figura 11-A). O contraste da paisagem edificada com o pano de fundo da serra do Faina promove destaque ainda maior para a igreja (figura 11-B), cuja estética é passível de admiração tanto de dia quanto de noite, com as luzes acesas.

Nesse trecho, ainda se percebe que não há sinalização, faixas de pedestres nos cruzamentos e arborização nas ruas. Não há proteção contra intempéries e o calçamento estreito, de pavimentação descontínua, com desníveis e obstáculos, exige do passante atenção redobrada. A carência de boa caminhabilidade, entretanto, acaba minimizada pelo forte apelo imagético do local, com encantador casario que volta à escala térrea, aproximando-se do pedestre, com utilização mista e fluxo moderado em seu calçamento. A própria edificação que abriga o banco, internamente dotada da tecnologia que a atividade requer, externamente dialoga com a paisagem cultural tombada da cidade, mantendo a tipologia colonial do casario onde se insere (figura 11-C). 

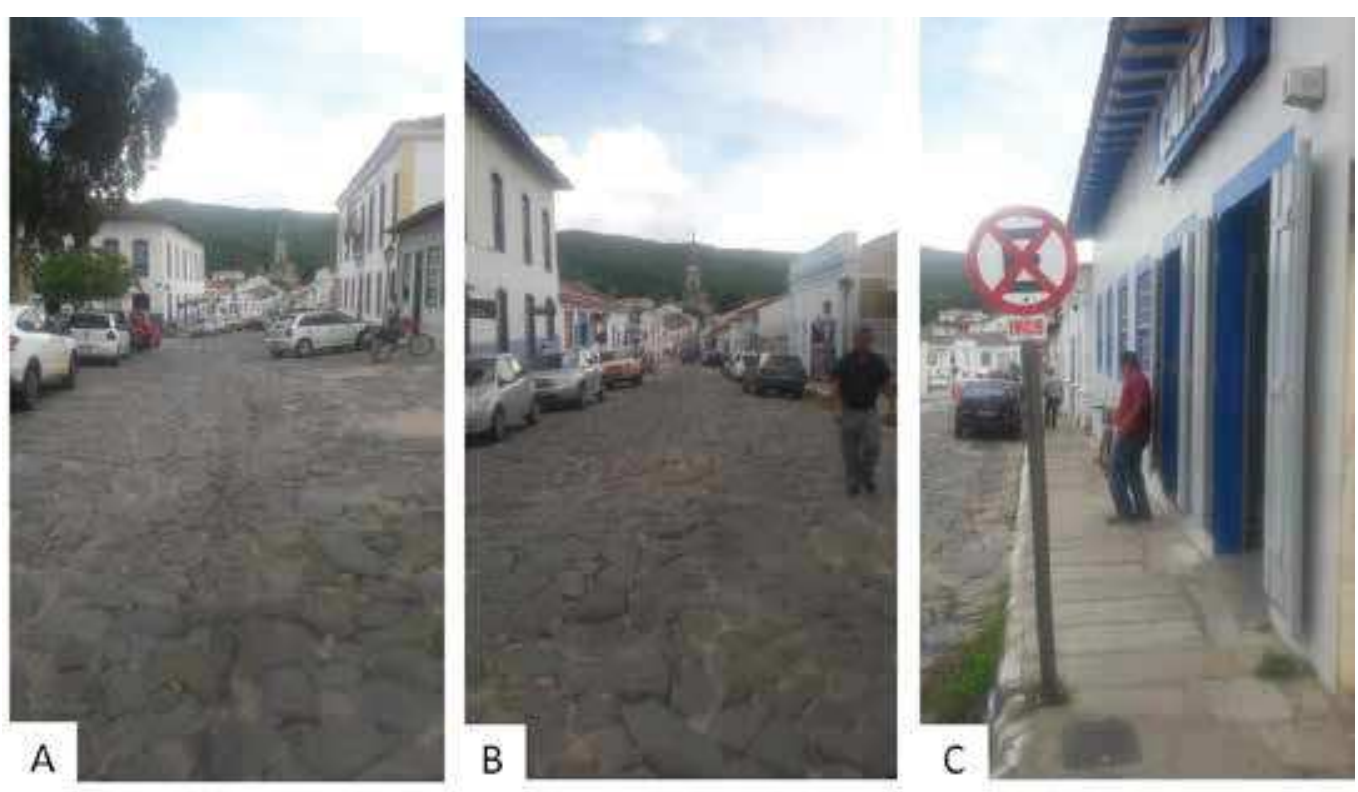

Figuras 11-A, 11-B e 11-C Descida na rua do banco.

Fotos: Carina Cardoso, 2016.

Quadro 6 Percurso residência-hospital: notas de caminhabilidade

\begin{tabular}{|c|c|c|c|}
\hline Categoria & $\begin{array}{l}\text { Média aritmética dos } \\
\text { trechos } \\
1,2,9,12,15,16 \text { e } 17\end{array}$ & Categoria & $\begin{array}{l}\text { Média aritmética dos } \\
\text { trechos } \\
1,2,9,12,15,16 \text { e } 17\end{array}$ \\
\hline Largura da calçada & 1,07 & $\begin{array}{l}\text { Usos lindeiros } \\
\text { ao trajeto }\end{array}$ & 2,83 \\
\hline $\begin{array}{l}\text { Condições de } \\
\text { pavimentação }\end{array}$ & 1,26 & $\begin{array}{l}\text { Segurança e } \\
\text { orientação }\end{array}$ & 0 \\
\hline Obstáculos & 1,36 & $\begin{array}{l}\text { Qualidade da } \\
\text { paisagem }\end{array}$ & 3 \\
\hline $\begin{array}{l}\text { Proteção contra } \\
\text { intempéries }\end{array}$ & 0,42 & Vegetação & 0,86 \\
\hline $\begin{array}{l}\text { Mobiliário urbano de } \\
\text { apoio }\end{array}$ & 1,43 & Topografia & 2,86 \\
\hline Iluminação pública & 3,14 & $\begin{array}{c}\text { Média Final do } \\
\text { Percurso }\end{array}$ & 1,66 \\
\hline
\end{tabular}

Fonte: Produzido pelos autores, 2016.

O percurso que parte da residência em direção ao hospital é o mesmo até o ponto identificado pelo lazer. Aí, a caracterização dos trechos 12 e 13, descrita nos percursos anteriores, coincide com o que se vê no 15 - e não gratuitamente: esses trechos configuram três dos quatro lados da praça do Coreto (figura 10). A paisagem muda a partir da conversão à esquerda no trecho 16 , onde a amplitude dá lugar novamente às ruas estreitas, com ausência de árvores e onde novamente há carência de calçadas largas em bom estado de conservação e com continuidade, sinalização, mobiliário urbano de apoio e proteção contra intempéries (figura 12-A). O trecho plano tem fluxo moderado, 
com uso misto de seus espaços, que guardam estreita relação com o transeunte, com ele dialogando em escala de proximidade. Esse tratamento humanizado do espaço já não existe no trecho seguinte, o 17. Complexo, poderia ser parcelado em vários trechos menores, tamanha é sua diversidade. Inicialmente, segue ladeado pelo casario histórico de uso misto, como visto no trecho anterior, contudo quase não há movimentação em suas calçadas (figura 12-B). Tal fato se justifica pela grande quantidade de edificações fechadas e sem uso. A noção de Cora de uma paisagem triste, ausente e de ar sombrio pode ser encontrada no início desse trecho, sobretudo se percorrido à noite. Mas a tal área se segue uma charmosa ponte que cruza o rio Vermelho, levando ao principal hospital da cidade (figura 12-C).
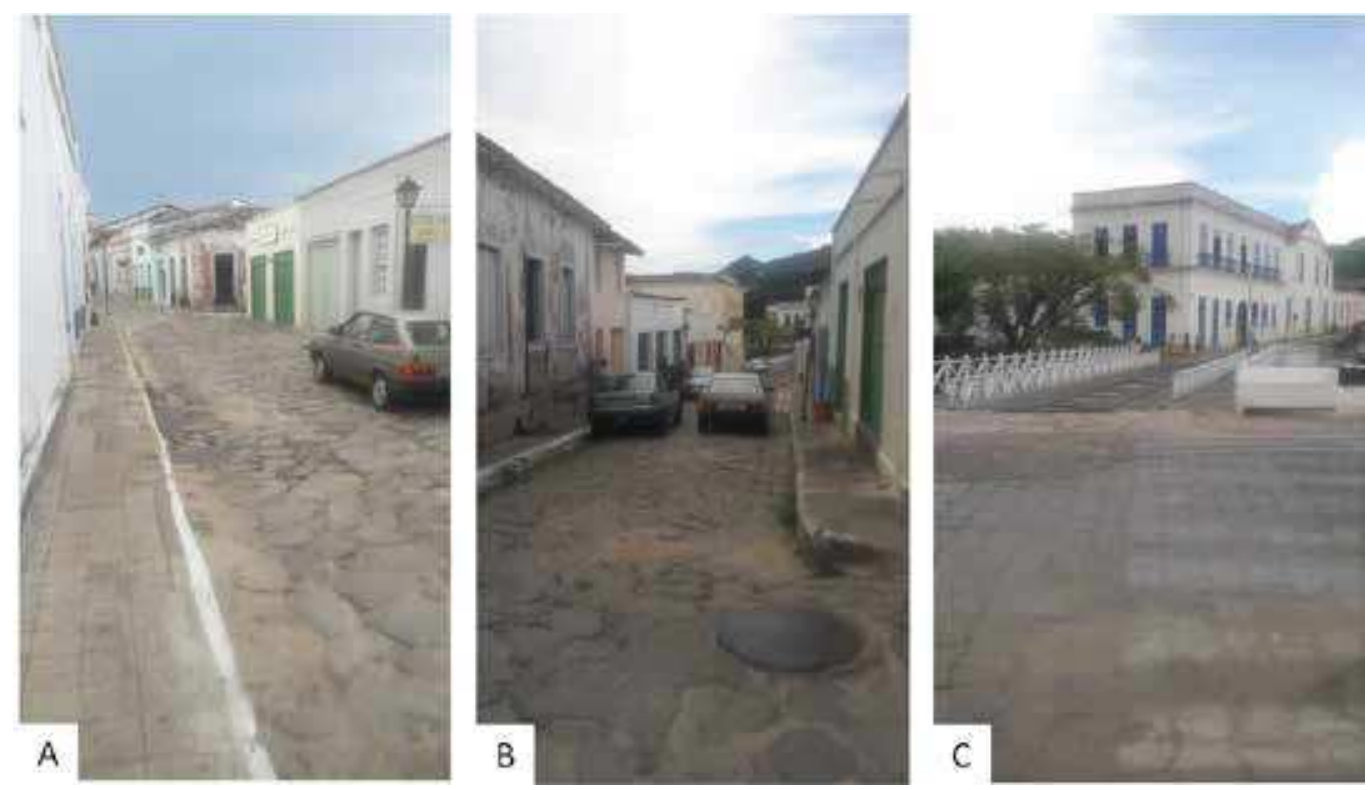

Figuras 12-A, 12-B e 12-C Trechos entre a praça do Coreto e a rua do hospital. Fotos: Carina Cardoso, 2016.

A travessia para o hospital é, entretanto, difícil. O trecho cruza um espaço amplo da larga via à beira-rio, onde não há sinalização eficaz ou faixa de pedestres. $\bigcirc$ caminhar sobre a ponte é separado do tráfego motorizado por uma barreira física baixa e muito tênue, não ofertando segurança para o transeunte. A iluminação é eficaz, como em todo o restante dos percursos, mas ao contrário do que o imaginário poderia supor, não há vegetação junto ao rio. Apenas a margem oposta, atravessada ao final do trecho 17 e próxima ao hospital detém maior número de árvores.

A umidade do rio Vermelho, que corta a cidade de Goiás, juntamente à sua configuração geológica, topográfica e vegetativa, possui grande influência no microclima da área. Ao cruzar o rio, às margens do qual se localiza a antiga casa da poetisa Cora Coralina ${ }^{4}$, a temperatura cai, a ventilação se acentua e promove relações sensoriais de

A casa que pertenceu à família de Cora Coralina e onde a escritora viveu até sua morte, em 1985, foi convertida em um Museu-Casa aberto à visitação pública. 
outra natureza ao transeunte. Esse agente limítrofe de porções urbanizadas e condições climatológicas atua no imaginário urbano como divisor de dois centros históricos que se unem nos traços estéticos do colonial e se distanciam nos aspectos que compõem a ambiência. Mais próximos da casa de Cora, a bucólica Goiás sinestésica se revela a quem por ela caminha.

\section{CONSIDERAÇÕES FINAIS}

Este trabalho se desenvolveu a partir de uma questão norteadora que propunha relacionar os níveis de caminhabilidade em trajetos cotidianos no centro histórico da cidade de Goiás com a contemplação da paisagem formada pelo conjunto colonial. Os resultados acerca do favorecimento da caminhabilidade na área em questão se mostraram preocupantes, com índices abaixo da média para todos os percursos. Com tais resultados dificilmente seria possível enquadrar a cidade de Goiás no rol das chamadas "cidades ativas". Apesar de seu pequeno porte, seus serviços essenciais se encontram a grandes distâncias das áreas residenciais da maior parte da população. A insolação hostil, a exposição a elevadas temperaturas, a topografia acidentada e a configuração da infraestrutura viária colonial, com calçadas pequenas e muitas irregularidades de pavimentação, são alguns dos fatores inibidores do deslocamento a pé. Somados a estes, o grande quantitativo de casarões abandonados ou fechados acaba por evanescer todo o potencial de ativação da paisagem construída colonial. Em uma escala amistosa e proporcional ao espaço público e à escala humana, com aberturas ritmadas e grande potencial de interlocução com a rua, muitas edificações de indiscutível valor estético, ao não estarem em uso frequente, se portam como enclaves, encerradas ao espaço público, conferindo a este uma atmosfera de esvaziamento e insegurança.

Entretanto, conforme discutido neste trabalho, o encantamento no ato de caminhar pela cidade não está centrado somente no 'aqui', na visão segmentária de trechos proposta frequentemente na análise de caminhabilidade. Pelo contrário, ele se desenvolve na intermediação do 'aqui' e do 'além', no surgimento ora progressivo, ora surpreendente da paisagem, cujo potencial é evidente na conformação do tecido colonial. A cada viela que desemboca em um largo, a cada grandiosa construção implantada em um ponto nodal, enquadrada nas perspectivas sucessivas, a cada marco paisagístico focalizado, a cada sequência de contrastes entre o caiado das edificações e as serras verdejadas, tem-se contato com o que instiga, com o que leva à locomoção, apesar das longas distâncias e das precariedades do espaço físico.

É importante sinalizar que a instigação é o propulsor do passeante. Para o habitante de Goiás, a paisagem pode tornar-se ordinária, tal qual seus percursos, e por si está longe de ser fator preponderante na opção pelo caminhar. Para o cidadão, mais do que a paisagem, a ambiência se torna vital: o conforto e a segurança de deslocar-se no espaço. Portanto, intervenções urbanas que se lancem ao desafio de melhorar as condições de caminhabilidade sem descaracterizar ou interromper a fruição da paisagem cultural são essenciais para maior vitalidade e humanização do espaço público 
a partir do convite ao deslocamento a pé. Os resultados apresentados neste estudo podem sinalizar passos iniciais em direção a essas boas práticas de ações no centro histórico da cidade.

Finalizando, o que se evidencia a partir deste trabalho é que a análise de caminhabilidade, apesar de contemplar a paisagem - fator primordial no incentivo ao passeio a pé -, o faz de forma segmentária e pouco sensível ao olhar do observador. Isso ocorre porque a necessidade de formular categorias e cenários acaba por restringir o inusitado, o emergente que somente a vivência do espaço e a sensibilidade podem revelar. Esses aspectos sensíveis também são pouco passíveis de valoração objetiva, contudo a incorporação da abordagem experiencial e a do registro serial das visões do espaço à análise de caminhabilidade são caminhos para a qualificação humanizada e subjetiva dos trajetos percorridos na cidade. 


\section{REFERÊNCIAS BIBLIOGRÁFICAS}

ALLEN, E.; FARR, D. Um bairro completo. In: FARR, D (Org.). Urbanismo sustentável: desenho urbano com a natureza. Porto Alegre: Bookman, 2013.

BARROS, A. P. B. G.; MARTíNEZ, L. M. G.; VIEGAS, J. M. A caminhabilidade sob a ótica das pessoas: o que promove e o que inibe o deslocamento a pé? Ur, Barcelona, n. 8, 2015, p. 94-103.

BORGOGNI, A. Active city: il movimento è protagonista. In: Il Manifesto, Itália, 14 set. 2013, Sport, s/p.

CARERI, F. Walkscapes: el andar como práctica estética. Barcelona: Gustavo Gilli, 2002.

CORALINA, C. Poemas e becos de Goiás e estórias mais. São Paulo: Círculo do Livro, 1989.

CULLEN, G. Paisagem urbana. Lisboa: Edições 70, 2010.

DORATO, E. La città attiva: mutamenti e nuove pratiche nell'uso dello spazio pubblico. In: Inforum, 2014, p.13-

18. Disponível em: <https://www.researchgate.net/publication/278403739>. Acesso em: 24 nov. 2016.

GEHL, J. Cidades para pessoas. 2 ed. São Paulo: Perspectiva, 2013.

GHIDINI, R. A caminhabilidade: medida urbana sustentável. Revista dos Transportes Públicos - ANTP. São Paulo: ANTP, v. 33, 2011 , p. $21-33$.

GONÇALVES et al. Avaliação da caminhabilidade nas ruas da cidade. Revista Mirante. Anápolis: UEG, v. 8, 2015, p. 185-2001.

LATOUR, B. A esperança de Pandora. Bauru: Edusc, 2001.

LOPES, A. R. A cidade sob a poética do andar: as deambulações de Hélio Oiticica. 2012. 189 f. Tese (Doutorado em Teoria e História da Arquitetura e Urbanismo) - Instituto de Arquitetura e Urbanismo da Universidade de São Paulo, São Carlos, 2012.

LYNCH, K. A imagem da cidade. São Paulo: Martins Fontes, 1997.

NANYA, L. M.; SANCHES, S. P. Proposta de instrumento para auditoria e avaliação da caminhabilidade. In: CONGRESSO NACIONAL DE PESQUISA EM TRANSPORTE DA ANPET, 2015, Ouro Preto. Anais... Ouro Preto: ANTP, 2015, p. 81-94.

PANERAI, P. Análise urbana. Brasília: EDU, 2014.

REY, S. Caminhar: experiência estética, desdobramento virtual. Revista Porto Arte, v. 17, n. 29, 2010, p.107-121.

SÁNCHEZ, E. R.; CAMPILLO, H. O. Andar: movilidad sostenible. Módulo Arquitectura CUC. Barranquilla: Educosta, v. 12, n. 1, 2013, p. 27-44.

SCHELLE, K. G. A arte de passear. São Paulo: Martins Fontes, 2001.

SPECK, J. Walkable city: how downtown can save America, one step at a time. New York: Farrar, Straus and Giroux, 2012.

Data de submissão: 30 nov. 2016

Data de aprovação: 4 mai. 2017 